\title{
EKSPLORASI GEOMAGNETIK UNTUK PENENTUAN KEBERADAAN PIPA AIR DI BAWAH PERMUKAAN BUMI
}

\author{
Widya Utama, Dwa Desa Warnana, Anik Hilyah, Syaeful Bahri, \\ Firman Syaifuddin, Hasibatul Farida R \\ Jurusan Teknik Geofisika, FTSP Institut Teknologi Sepuluh Nopember \\ e-mail:widya@geofisika.its.ac.id
}

\begin{abstract}
Abstrak. Dalam penerapannya, metode geomagnetik dipakai untuk memetakan struktur perlapisan di bawah permukaan atau deposit mineral logam yang bersifat feromagnetik. Metode ini tergolong pasif karena menggunakan medan magnet bumi sebagai sumbernya. Dalam penelitian ini, telah dilakukan pengukuran medan magnetik bumi untuk mengetahui keberadaan pipa air (hidrant) yang tertanam di bawah permukaan tanah, di taman BAAK kampus ITS. Pengukuran medan magnetik bumi dilakukan dalam bentuk jejaring titik ukur dengan lintasan sejumlah 10 dan jarak antar titik ukur adalah 5 m. Pada saat dilakukan pengukuran, terdapat lalu lalang beberapa kendaraan bermotor yang tidak bisa dihindari. Pengukuran medan magnetik dilakukan dengan menggunakan proton magnetometer. Sebagai titik referensi, dipilih sebuah titik Base Station (BS) yang bebas dari pengaruh benda logam. Data medan magnet terukur harus dikoreksi untuk memperoleh nilai anomali medan magnetik. Nilai anomali tersebut berasosiasi dengan keberadaan benda target eksplorasi geomagnetik. Koreksi yang dilakukan adalah koreksi diurnal (yang mengacu ke titik BS) dan koreksi standar IGRF (sebagai acuan, yaitu nilai medan magnet bumi normal). Peta kontur medan magnetik anomali diperoleh dengan software Surfer. Filtering dengan low pass filter dilakukan untuk menihilkan pengaruh magnetik yang ditimbulkan oleh lalu lintas kendaraan bermotor yang lewat selama masa pengukuran. Peta kontur tersebut diolah lebih lanjut dengan software Magpick dan Mag2DC untuk mempertegas keberadaan benda penyebab anomali magnetik. Berdasarkan hasil perhitungan model anomali, dapat diperoleh distribusi nilai suseptibilitas magnetik. Dengan demikian, dapat ditentukan secara kualitatif keberadaan benda anomali berdasarkan perbedaan nilai suseptibilitas di bawah permukaan tanah. Untuk pembangunan infrastruktur, metode geomagnetik dipakai sebagai langkah awal untuk memahami kondisi dan struktur pelapisan bawah tanah, serta dapat memberi arti efisiensi dalam perencanaan pekerjaan pembangunan infrastruktur.
\end{abstract}

Kata kunci: geomagnetik; feromagnetik; suseptibilita; filtering; anomali magnetik

Abstract. In application, geomagnetic method used to map the structure of subsurface layering or mineral deposits that are ferromagnetic metal. This method is relatively passive because it uses the Earth's magnetic field as a source. In this study, we conducted measurements of Earth's magnetic field to determine the presence of water pipe (hidrant) which is embedded below ground level, in the garden $B A A K$, ITS campus. Measurement of Earth's magnetic field is done in the form of a network measuring point with the 10 tracks, and the distance between the measuring point is $5 \mathrm{~m}$. At the time of measurement, there are passing several vehicles that can not be avoided. Magnetic field measurements performed use a proton magnetometer. As a reference point, selected a point Base Station (BS) which is free from the influence of metal objects. The measured magnetic field data must be corrected to obtain the value of the magnetic field anomalies. The anomalous values are associated with the presence of the geomagnetic exploration target object. Corrections made are diurnal correction (which refers to the BS point) and a standard IGRF correction (as a reference, the normal value of the earth's magnetic field). Magnetic field anomaly contour map obtained by Surfer software. Filtering with a low pass filter is done to nullify the magnetic effect caused by motor vehicle traffic passing over the measurement period. The contour map is processed further with the software Magpick and Mag2DC for making a point where the object causing the magnetic anomaly. Based on the calculation model of the anomalies, may be obtained distribution of the magnetic suseptibilitas value. Thus, it can be determined qualitatively the presence of anomalous objects based on differences in susceptibility values below ground level. For infrastructure development, the geomagnetic method is used as a first step to understand the condition and structure of the basement coating, and can give the sense of efficiency in the planning of infrastructure works.

Keywords: geomagnetic; ferromagnetic; susceptibility; filtering; magnetic anomalies 


\section{PENDAHULUAN}

Ilmu geofisika merupakan disiplin ilmu yang mempelajari bumi beserta isinya dengan menggunakan prinsip-prinsip fisika, seperti perambatan gelombang, listrik, medan magnet, dan medan gravitasi bumi. Umumnya ilmu geofisika berperan dalam hal interpretasi struktur maupun mineral-mineral di bawah permukaan bumi (Dobrin dan Savit, 1988). Banyak sekali metode-metode yang telah dikembangkan untuk pemetaan struktur bawah permukaan tersebut. Salah satu dari metode tersebut adalah metode geomagnetik. Metode geomagnetik adalah metode yang digunakan untuk menyelidiki kondisi permukaan bumi dengan memanfaatkan sifat kemagnetan batuan yang diidentifikasikan oleh kerentanan magnet batuan.

Metode ini didasarkan pada pengukuran variasi intensitas magnetik di permukaan bumi yang disebabkan adanya variasi distribusi (anomali) benda termagnetisasi di bawah permukaan bumi. Variasi intensitas medan magnetik yang terukur kemudian ditafsirkan dalam bentuk distribusi bahan magnetik dibawah permukaan, kemudian dijadikan dasar bagi pendugaan keadaan geologi yang mungkin teramati. Pengukuran intensitas medan magnetik dapat dilakukan di darat, laut maupun udara. Suseptibilitas magnet batuan adalah harga magnet suatu batuan terhadap pengaruh magnet, yang pada umumnya erat kaitannya dengan kandungan mineral. Semakin besar kandungan mineral magnetit di dalam batuan, akan semakin besar harga suseptibilitasnya. Perbedaan permeabilitas itu sendiri pada dasarnya diakibatkan oleh perbedaan distribusi mineral yang bersifat ferromagnetik, paramagnetik, dan diamagnetik.

Metode magnetik sering dijadikan survei awal dalam kegiatan eksplorasi minyak bumi, panas bumi, dan batuan mineral. Selain itu metode geomagnetik juga dapat digunakan untuk mendeteksi benda-benda feromagnetik yang memang sengaja ditanam dalam tanah, misalnya pipa air bawah tanah, atau kabel bawah tanah.
Penelitian ini dilakukan di lingkunagn ITS yaitu daerah taman BAAK ITS dengan dimensi $50 \times 50$ meter dan terdapat 10 line pengukuran dengan jarak 5 meter pada masing-masing titik. Tujuan dilakukannya penelitian ini adalah untuk mengetahui letak pipa hydrant yang tertanam di dalam tanah di lokasi tersebut. Dalam setiap pengukuran tiap titik akan diperoleh nilai medan magnet, kordinat, dan waktu pengukuran. Kondisi saat pengukuran dilakukan terdapat beberapa kendaraan bermotor yang lewat dan tak terhindarkan, dimana ini akan berpengaruh pada nilai medan magnet yang dihasilkan.

\section{Teori Magnetik}

Metode magnetik adalah salah satu metode geofisika untuk mengukur variasi medan magnetik di permukaan bumi yang disebabkan oleh adanya variasi distribusi benda termagnetisasi di bawah permukaan bumi. Variasi intensitas medan magnet akan ditafsirkan dan kemudian dijadikan dasar bagi pendugaan keadaan geologi. Apabila terdapat dua buah kutub magnetik yang berjarak $r$ dalam centimeter, maka akan terjadi gaya Coulumb sebesar.

$$
F=\frac{1}{\mu} \frac{m_{1} m_{2}}{r^{2}}
$$

Medan magnet bumi merupakan suatu medan atau daerah yang dapat mendeteksi keberadaan dan distribusi gaya magnet. Kuat medan magnet $\mathrm{H}$ didefinisikan sebagai gaya magnet per satuan kuat kutub magnet. Kuat medan magnet pada suatu titik yang berada pada jarak $r$ dari kutub magnet $m$ dapat dinyatakan sebagai berikut.

$$
H=\frac{1}{\mu} \frac{m}{r^{2}}
$$

(Telford dkk., 1976) 
Medan magnet bumi sendiri memiliki empat parameter fisis, yaitu deklinasi (D), sainklinasi (I), intensitas horizontal $(H)$, dan medan magnetik total (F). Deklinasi merupakan sudut antara Utara magnetik dengan komponen horizontal yang dihitung dari Utara menuju Timur. Inklinasi merupakan sudut antara medan magnetik total dengan bidang horizontal yang dihitung dari bidang horizontal menuju bidang vertical ke bawah. Sedangkan intensitas horizontal adalah besar medan magnet total pada bidang horizontal dan magnetik total itu sendiri merupakan besar dari vektor medan magnetik total. Medan magnet utama bumi dapat berubah terhadap waktu.

Jika suatu bahan magnetik ditempatkan dalam medan magnetik $\mathrm{H}$, bahan tersebut akan termagnetisasi. Intensitas magnetisasi (M) berkaitan dengan kuat medan magnetik melalui konstansta kesebandingan ks, yang dikenal sebagai suseptibilitas magnetik.

Hubungan intensitas magnetisasi dengan suseptibilitas magnetik diungkapkan dalam:

$$
M=k H
$$

Berdasarkan respon suatu bahan terhadap medan magnetik luar, bahan magnetik dapat dikelompokkan ke dalam tiga jenis, yaitu.

1. Diamagnetik

Bahan diamagnetik mempunyai nilai suseptibilitas magnetik yang kecil. Bahan diamagnetik memiliki arah magnetisasi yang berlawanan dengan arah medan magnetik luar sehingga bahan diamagnetik mempunyai nilai suseptibilitas magnetik negatif. Suseptibilitas magnetik bahan diamagnetik tidak bergantung pada temperatur. Seperti mineral bismuth, grafit, gipsum, marmer, dan kuarsa.



Gambar 1. Arah Polarisasi Diamagnetik (Rosid, 2008).
2. Paramagnetik

Bahan paramagnetik memiliki nilai suseptibilitas magnetik yang kecil dan positif. Arah magnetisasi dari bahan paramagnetik sama dengan dengan arah medan magnetik luar sehingga memiliki suseptibilitas magnetik positif. Nilai suseptibilitas magnetik bahan paramagnetik bergantung pada temperatur.

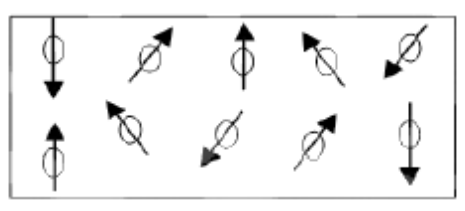

Gambar 2. Arah Polarisasi Paramagnetik (Rosid, 2008).

3. Ferromagnetik (termasuk ferrimagnetik, antiferromagnetik)

Bahan ferromagnetik memiliki nilai suseptibilitas magnetik positif dan besar. Seperti halnya bahan paramagnetik, sifat kemagnetan bahan ferromagnetik dipengaruhi oleh temperatur. Seperti mineral besi, nikel, dan kobalt.

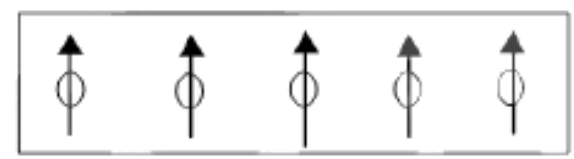

Gambar 3. Arah Polarisasi Ferromagnetik (Rosid, 2008).

Medan magnet bumi terdiri dari tiga bagian, yaitu:

1. Medan magnetik utama

Medan magnetik utama ini tidak konstan dalam waktu dan berubah relatif lamban dan asal perubahan dari perubahan internal dalam bumi, yang dapat dihubungkan dengan perubahan arus konveksi dalam inti, perubahan inti mantel, dan perubahan dalam laju perputaran bumi. 


\section{Medan luar}

Merupakan bagian kecil medan utama, yaitu sisa $1 \%$ medan magnetik bumi, berasal dari luar bumi yang berhubungan dengan arus listrik yang mengalir dalam lapisan terionisasi atmosfir luar. Perubahan medan ini terhadap waktu jauh lebih cepat dari pada medan permanen.

3. Anomali magnetik lokal

Dekat permukaan kerak bumi merupakan penyebab perubahan dalam medan utama yang biasanya jauh lebih kecil dari medan utama, relatif konstan dalam waktu dan tempat. Perubahan ini dapat dihubungkan dengan perubahan kandungan mineral magnetik dalam batu-batuan dekat permukaan. Kadang-kadang anomali ini cukup besar sehingga besar medan menjadi dua kali lipat dibanding medan utama dangkal. Pada umumnya anomali ini tidak menyebar ke daerah luas karena sumbernya tidak terletak dalam (Telford dkk., 1976).

\section{Koreksi Data Magnetik}

Untuk mendapatkan anomali medan magnet, maka data yang diperoleh harus dikoreksi terlebih dahulu dari pengaruh medan magnet yang lain. Secara umum koreksi yang dilakukan dalam survey magnetik meliputi:

1. Koreksi harian (diurnal)

Merupakan koreksi yang dilakukan terhadap data magnetik untuk menghilangkan pengaruh medan magnet luar. Koreksi harian merupakan variasi medan magnet yang sebagian bersumber dari medan magnet luar akibat perputaran arus listrik di dalam lapisan ionosfer.

Apabila nilai variasi harian negatif, maka koreksi harian dilakukan dengan cara menambahkan nilai variasi harian yang terekam pada waktu tertentu terhadap data medan magnetik yang akan dikoreksi. Sebaliknya apabila variasi harian bernilai positif, maka koreksinya dilakukan dengan cara mengurangkan nilai variasi harian yang terekam pada waktu tertentu terhadap data medan magnetik yang akan dikoreksi. Secara matematis dapat dituliskan dalam persamaan.

$$
\Delta \mathrm{H}=\mathrm{H}_{\text {total }} \pm \Delta \mathrm{H}_{\text {harian }}
$$

\section{Koreksi IGRF}

Merupakan koreksi yang dilakukan terhadap data medan magnet agar pengaruh medan magnet utama bumi hilang, dimana mean magnet IGRF adalah referensi medan magnet di suatu tempat. Koreksi geomagnet diperlukan karena medan magnet bumi bergerak dari kutub ke khatulistiwa. IGRF mendefinisikan magnet teoritis tidak terganggu pada setiap titik di permukaan bumi. Koreksi IGRF adalah koreksi secara regional yang dilakukan terhadap data magnet terukur untuk menghilangkan pengaruh medan utama magnet bumi. Koreksi ini dilakukan dengan cara mengurangkan nilai medan magnet yang terbaca dengan IGRF daerah tersebut.

3. Koreksi drift

Koreksi drift dilakukan karena adanya perbedaan harga bacaan magnetometer pada titik yang sama jika pengukuran membentuk loop. Adanya perbedaan bacaan tersebut salah satunya akibat berkurangnya fluida pada sensor alat.

4. Koreksi kutub

Koreksi kutub atau istilah lainnya adalah reduce to pole (reduksi ke kutub) adalah salah satu koreksi anomali magnetik yang dilakukan untuk memudahkan saat proses interpretasi. Cara yang dilakukan adalah dengan cara mengubah sudut deklinasi menjadi $90^{\circ}$ dan inklinasi menjadi $0^{\circ}$.

5. Koreksi ketinggian

Koreksi ketinggian atau Upward Continuation merupakan proses reduksi data magnetik terhadap ketinggian. Agar dapat menekan noise berfrekuensi tinggi dengan benda-benda magnetik di sekitarnya. Penentuan nilai ketinggian dapat disesuaikan tergantung efek yang ingin ditampilkan atau dihilangkan. Besar 
ketinggian yang digunakan untuk mengangkat bidang pengamat tidak boleh terlalu besar karena dapat mengakbatkan hilangnya informasi pada daerah tersebut dalam (Telford dkk., 1976).

\section{Geologi Surabaya}

Surabaya merupakan ibu kota dari Propinsi Jawa Timur. Secara geografis berada pada $07^{\circ} 09^{\circ} 00^{\prime \prime}-07^{\circ} 21^{\prime} 00^{\prime \prime}$ Lintang Selatan dan $112^{\circ} 36^{\prime}$ $112^{\circ} 54^{`}$ Bujur Timur. Luas wilayah Kota Surabaya meliputi daratan dengan luas 330,48 km2 dan lautan seluas $190,39 \mathrm{~km} 2$. Secara luas keseluruhan wilayah kota Surabaya adalah $33.048 \mathrm{Ha}$. Wilayah Surabaya umumnya terbagi menjadi lima wilayah yaitu Surabaya Pusat, Surabaya Timur, Surabaya Barat, Surabaya Selatan, dan Surabaya Utara. Ketinggian tanah Kota Surabaya antara 0-20 meter di atas permukaan laut. Sedangkan pada daerah pantai ketinggian berkisar antara 1-3 meter di atas permukaan laut.

Wilayah kota Surabaya didominasi daerah dataran rendah (Surabaya Timur, Utara, Selatan) yang terbentuk dari endapan alluvial sungai dan endapan pantai. Sisanya merupakan perbukitan rendah yang terbentuk dari tanah hasil pelapukan batuan tersier.

Dataran rendah bagian Tengah kota Surabaya terbentuk oleh endapan Sungai Brantas beserta cabang-cabang sungainya dan endapan Sungai Rowo. Endapan Sungai Brantas berasal dari letusan gunung-gunung berapi yang berada di hulu dan beberapa rombakan sebelumnya. Endapan ini biasanya berupa pasir $(0,075 \mathrm{~mm}-0.2 \mathrm{~mm})$ dan kerikil ( $2 \mathrm{~mm}-75 \mathrm{~mm}$ ). Bagian Timur dan Utara sampai sepanjang Selat Madura dibentuk oleh endapan pantai yang masuk ke daratan sampai \pm 5 $\mathrm{km}$. Endapan pantainya terdiri dari lempung lanau dan lempung kelanauan.

Secara geologi Surabaya terbentuk oleh batuan sedimen yang berumur Miosen sampai Plistosen. Batuan sedimennya adalah bagian dari lajur Kendeng dengan Formasi Sonde, Lidah, Pucangan, dan Kabuh. Batuan dasar untuk kota Surabaya merupakan formasi Lidah yang berumur Pliosen (pre-tertiary). Formasi ini berada pada kedalaman 250 - 300 meter. Selain itu, daerah Surabaya berupa cekungan endapan alluvial muda hasil endapan laut dan sungai, tuf, dan batu pasir (Soekardi, 1992).

\section{METODOLOGI}

Proses pengambilan data dalam penelitian ini dilakukan di lingkungan ITS yaitu daerah taman BAAK. Alat-alat yang dibutuhkan antara lain GPS untuk mengetahui titik koordinat pada tiap titik pengukuran, Proton Precisssion Magnetometer (PPM) untuk mengukur medan magnet, kompas geologi untuk menentukan arah Utara sensor PPM dan membantu menentukan posisi supaya urut, meteran 100 meter untuk mengukur jarak grid, dan Jam untuk menghitung waktu pengambilan data.

Pengukuran medan magnetik dilakukan dalam jejaring titik ukur yang teratur yang berdimensi 50x50 meter dengan lintasan sejumlah 10 dan jarak tiap titik 5 meter. Adapun Base Station (BS) terletak 20 meter dari lintasan 1. Pengukuran awal dilakukan di BS kemudian dilanjutkan pada lintasan, setiap selesai mengukur satu lintassan lalu kembali ke BS dan dilanjutkan dengan lintasan berikutnya. Waktu pengukuran dalam setiap lintasan dilakukan selama 10 menit.

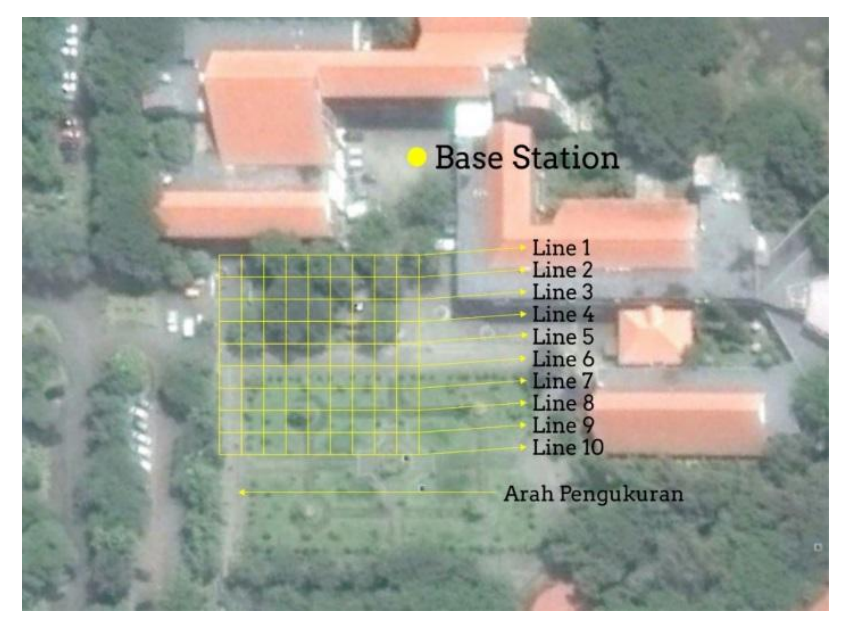

Gambar 4. Desain Pengukuran. 
Data yang didapatkan dari pengukuran ini adalah medan magnet total, nilai koordinat, dan waktu. Sebelum data-data tersebut diproses, data medan magnet total harus dilakukan koreksi diurnal dan IGRF sedangkan data koordinat dijadikan dalam bentuk UTM. Pengolahan data-data tersebut menggunakan beberapa software seperti Surfer 11, Magpick, dan Mag2DC, untuk dilakukan interpretasi secara kuantitatif dan kualitatif.

\section{HASIL DAN PEMBAHASAN}

Dalam percobaan ini pengukuran medan magnetik dipengaruhi oleh target anomali, variasi harian, data regional, dan noise saat dilakukan pengukuran seperti kendaran yang diparkir di lokasi pengukuran. Variasi harian diinterpolasikan pada pengukuran data magnetik dengan waktu. Data regional dikoreksi dengan nilai IGRF (International Geomagnetik Reference Field). Sedangkan noisenoise yang berfrekuensi tinggi dikoreksi dengan RTP (Reduce To Pole) dan UC (Upward Continuation) dengan elevasi 5 meter. Data medan magnet total yang telah dilakukan koreksi-koreksi, dijadikan dalam bentuk peta kontur, sehingga didapatkan peta anomali magnetik seperti Gambar 5 berikut.

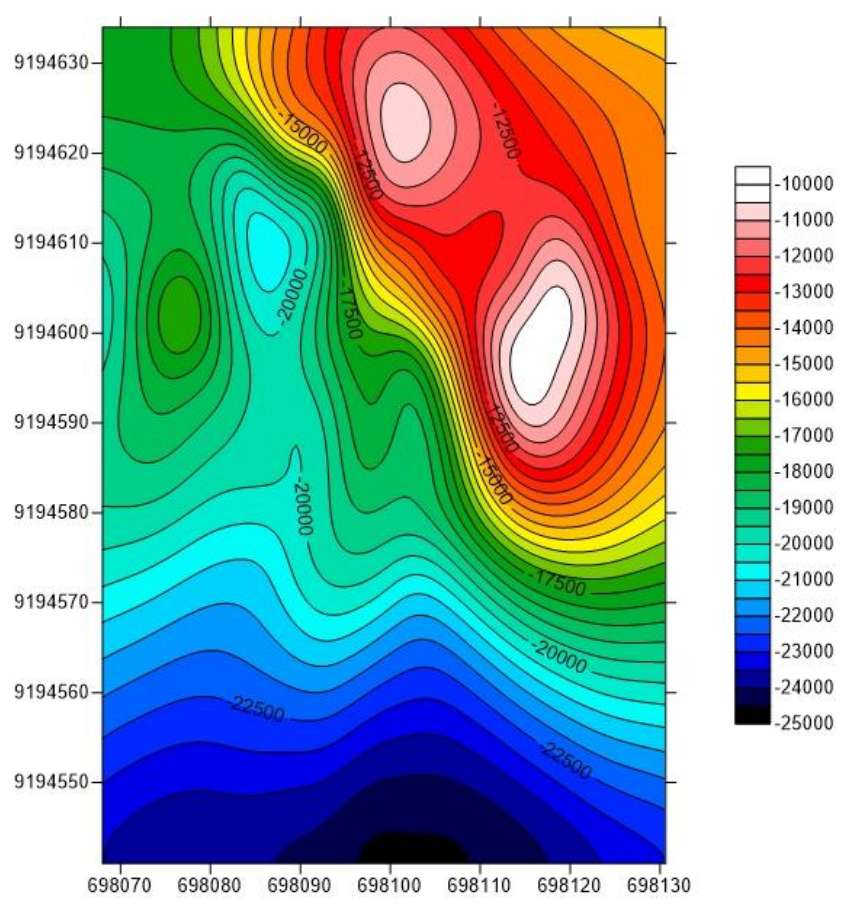

Gambar 5. Peta Anomali Magnetik dan Daerah yang di Slice.
Anomali magnetik yang dihasilkan dari pemodelan ini harus sesuai dengan anomali hasil observasi sebelum dilakukan pengukuran. Apabila anomali yang dihasilkan dari pemodelan sudah sesuai dengan anomali observasi, maka posisi bentuk dan parameter model dapat diasumsikan dan diinterpretasikan sebagai posisi, bentuk dan parameter dari benda yang sebenarnya. Peta anomali magnetik di atas kemudian diinterpretasi dengan software Mag2DC, dan dilakukan slicing pada daerah yang interest, yaitu yang berwarna biru tua yang ditunjukkan dengan garis oranye pada Gambar 5.

Data hasil slicing tersebut kemudian diproses dengan software Mag2DC sehingga didapatkan perkiraan benda penyebab anomali seperti Gambar 6. Pemodelan semacam ini disebut dengan pemodelan Talwani yaitu menggunakan metode poligon untuk memodelkan struktur di bawah permukaan bumi.

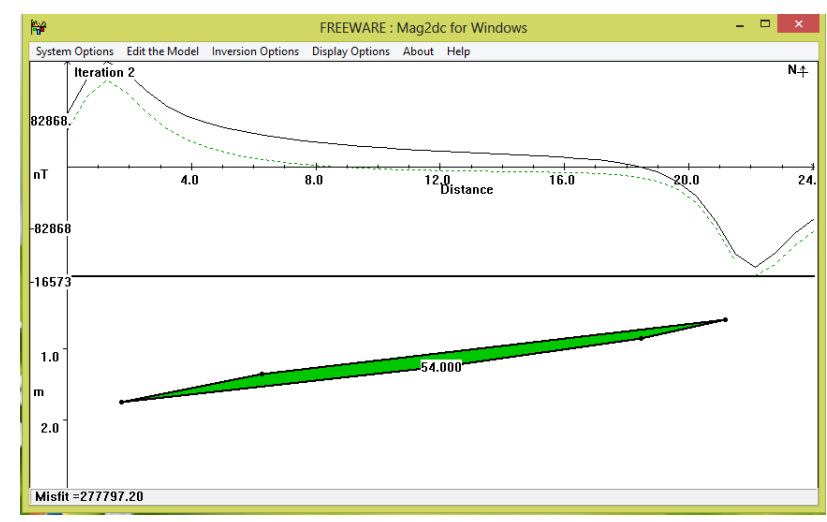

Gambar 6. Hasil Interpretasi dengan Software Mag2DC.

Berdasarkan gambar di atas, diketahui bahwa lapisan yang berwarna putih memiliki suseptibilitas 0,02 dan diperkirakan merupakan lapisan tanah alluvial. Sedangkan model yang berwarna hijau memiliki suseptibilitas 54. Berdasarkan teori diketahui bahwa mineral hematit $\left(\mathrm{Fe}_{2} \mathrm{O}_{3}\right)$ memiliki suseptibilitas yang berkisar antara 10-760 (Hunt dkk., 1995). Sehingga diperkirakan benda anomali ini merupakan besi yang berasal dari pipa hydrant yang menjadi target anomali dari pengukuran ini. Pipa hydrant ini terletak pada kedalaman 0,599 
meter dan terbentang pada arah Barat daya - Timur Laut.

Hasil interpretasi ini sesuai dengan observasi awal, dimana dari segi geologi daerah Surabaya $80 \%$ merupakan dataran rendah yang berupa endapan alluvial dan benda penyebab anomali berupa pipa hydrant yang tertanam di dalam tanah.

\section{PENUTUP}

\section{Simpulan}

Dari hasil pengukuran dan interpretasi yang telah dilakukan, maka dapat diambil beberapa kesimpulan sebagai berikut.

1. Peta kontur anomali magnetik daerah taman dan BAAK ITS memiliki nilai antara $-25.000 \mathrm{nT}$ s.d $10.000 \mathrm{nT}$.

2. Hasil pemodelan daerah slicing memiliki kedalaman maksimal 3 meter dan didominasi dengan lapisan endapan alluvial dengan suseptibilitas 0,02 .

3. Benda penyebab anomali memiliki suseptibilitas 54, terletak pada kedalaman 0,599 meter, dan terbentang pada arah Barat Daya - Timur Laut.

4. Diperkirakan benda penyebab anomali ini adalah besi yang berasal dari pipa hydrant.

\section{Saran}

Survei dengan metode magnetik merupakan survei awal dari suatu kegiatan eksplorasi. Sehingga hasilnya memiliki ambiguitas yang tinggi. Sehingga untuk mengetahui secara lebih detail kondisi bawah permukaan suatu daerah diperlukan pemahaman geologi yang matang serta survei lanjutan yang lebih akurat seperti metode seismik, geolistrik, dan lain sebagianya. Selain itu juga, perlu dilakukan pemodelan 3D untuk mendapatkan gambaran yang lebih detail mengenai struktur bawah permukaan daerah taman BAAK ITS.

\section{DAFTAR PUSTAKA}

Dobrin, M.B., Savit CH., 1988. Introduction to Geophysical Prospecting, edisi 4. Singapore: Mc Graw Hill.

Hunt, C.P., Moskowitz, B.M,. Banerjee, S.K., 1995. Magnetic Properties of Rocks and Minerals.

Robinson, Edwin and Cahit., 1988. Basic Exploration Geophysics Using Magnetic Method. John Wiley and Sons Inc.: Canada.

Rosid, Syamsu., 2008. Geomagnetic Method Lecture Note. Physic Departement, FMIPA UI: Depok.

Soekardi, 1992. Geologi Lembar Pacitan, Jawa, Pusat Penelitian dan Pengembangan Geologi Indonesia.

W. M. Telford, L. P. Geldart, R. E. Sheriff., 1990. Applied Geophysics. Cambridge University: Press New York. 
Jurnal Geosaintek. 02 / 03 Tahun 2016 